DOI 10.37882/2223-2982.2021.03.13

\title{
РАСШИРЕНИЕ РОДИТЕЛЬСКИХ КОМПЕТЕНЦИЙ В СФЕРЕ РАННЕГО РАЗВИТИЯ ДЕТЕЙ С СИНДРОМОМ ДАУНА
}

\section{EXPANDING PARENTAL COMPETENCIES IN THE FIELD OF EARLY DEVELOPMENT OF CHILDREN WITH DOWN SYNDROME}

\section{Gramatikopolo}

Summary: The article is devoted to the problem of a comprehensive study of the ways of forming parental competencies in family members raising children with Down syndrome at the early stages of ontogenesis. The analysis of diversity, direction and content of domestic and international programs aimed at increasing parental competence parents in families raising children with different disabilities. A brief analysis of the structure of parental competence of mothers raising young children with Down syndrome is presented. The content of general and specific parental competencies in mothers raising children with Down syndrome from an early age is specified. The prospects of applying the results of this study to further study the environmental factors that affect the effectiveness of rehabilitation (habilitation) of children with Down syndrome are determined.

Keywords: child with Down syndrome, parental competence, early development support programs, families raising children with disabilities.
Граматикополо Людмила Савельевна

Аспирант, МГПУ

888IIIsss@gmail.com

Аннотация: Статья посвящена проблеме комплексного изучения путей формирования родительских компетенций у членов семей, воспитывающих детей с синдромом Дауна на ранних этапах онтогенеза. Проведен анализ многообразия, направления и особенности содержания отечественных и зарубежных программ, направленных на расширение родительской компетентности родителей в семьях, воспитывающих детей с разными вариантами ограниченных возможностей здоровья. Представлен краткий анализ структуры родительской компетентности матерей, воспитывающих детей раннего возраста с синдромом Дауна. Конкретизировано содержание общих и специфических родительских компетенций у матерей, воспитывающих детей с раннего возраста с синдромом Дауна. Определены перспективы применения результатов данного исследования для дальнейшего изучения факторов окружающей среды, влияющих на эффективность реабилитации (абилитации) детей с синдромом Дауна.

Ключевые слова: ребенок с синдромом Дауна, родительская компетентность, программы сопровождения раннего развития, семьи, воспитывающие детей COB3.
$\mathrm{C}$ емья, воспитывающая ребенка с синдромом Дауна, в настоящее время может рассматриваться как уникальная система, обладающая необходимыми ресурсами не только для воспитания особенного ребенка, но и для координации и реализации комплексных мероприятий, направленных на стимуляцию его раннего развития, абилитацию и социализацию [1, 2].

Проведенный анализ изменений государственной политики в отношении детей раннего возраста с ограниченными возможностями здоровья (ОВ3) в Российской Федерации за последнее десятилетие показал, что к первостепенным мерам поддержки, принимаемым во всех регионах страны, относится модернизация существующей системы комплексной реабилитации (абилитации).

Новая методология ранней помощи детям с ОВ3 формируется на основе принципов биопсихосоциальной модели инвалидности, что обусловливает необходимость поиска оптимальных ресурсов и технологий достижения реабилитационных целей и задач на уровне микро-, мезо- и макросоциума $[2,3,5]$.

На уровне микросоциума такие реабилитационные ресурсы могут формироваться, расширяться и воспроизводиться в условиях семейных систем, воспитывающих особенного ребенка.

Современные подходы к выявлению и комплексной поддержке реабилитационных ресурсов семей, воспитывающих детей с синдромом Дауна, в России и за рубежом начали формироваться во второй половине XX века в связи с изменениями реабилитационной философии и появлением различных моделей инвалидности.

Именно в этот период впервые был выдвинут тезис о том, что семья, воспитывающая аномального ребенка, может рассматриваться как уникальная реабилитационная система, успешно сочетающая социализирующую и коррекционно-реабилитационную функции.

Однако такая система не является самодостаточной, она нуждается в поддержке извне. И в первую очередь, такая поддержка должна быть направлена на формирование у родителей системы специальных знаний, навыков и компетенций, необходимых для осуществления ухода, развития и воспитания особенного ребенка $[2,4$, 5]. 
По мнению многих авторов, изучавших особенности семей, воспитывающих детей с ОВ3, основой регуляции внутрисемейной ситуации развития особенного ребенка является система родительских установок, которая тесно связана с общими и специальными родительскими компетенциями $[1,2,3,4,5,6]$. Родительская компетентность матерей, воспитывающих ребенка с синдромом Дауна, имеет сложную структуру, основанную на когнитивно-аффективной ментальной модели, отражающей представления матери об основных целях, задачах, ее сфере ответственности и оптимальном объеме участия в процессе развития ребенка с нарушениями развития.

В структуре родительской компетентности матерей, воспитывающих детей с синдромом Дауна, можно выделить общие и специальные родительские компетенции. Общие родительские компетенции в сфере ухода, питания, эмоционального и социально-коммуникативного взаимодействия, стимуляции физического и психического развития ребенка раннего возраста характерны как для семей, воспитывающих нормотипичных детей, так и для семей, воспитывающих детей с отклонениями в развитии. Специальные родительские компетенции формируются преимущественно у членов семей, воспитывающих детей с ОВ3, в связи со спецификой осуществления ухода, необходимостью преодолевать и предупреждать вторично возникающие на фоне грубого органического поражения мозга нарушения физического, когнитивного, эмоционального и коммуникативно-речевого развития, негативно влияющие на возможности социализации ребенка с синдромом Дауна $[3,5]$.

В том случае, когда родительские компетенции матери оказываются не достаточными для решения ежедневных задач, связанных с уходом и воспитанием ребенка с синдромом Дауна, возникают риски их эмоционально-личностной деформации, появления дисфункционального стиля семейного воспитания, либо отказ от воспитания ребенка в условиях семьи. Такая ситуация, очевидно, имеет не только негативные социальные последствия, но и наносит значительный вред психоэмоциональному состоянию ребенка, задерживает и без того замедленный процесс его психофизического развития.

В связи с этим возникает необходимость разработки специальных персонифицированных программ сопровождения семей, воспитывающих детей с синдромом Дауна, которые включают работу по расширению специальных родительских компетенций в сфере раннего развития ребенка с синдромом Дауна.

Специальные программы формирования родительских компетенций в сфере раннего развития ребенка с синдромом Дауна, разрабатывались в рамках деятельности различных организаций.
В настоящее время наиболее популярными в России являются следующие программы поддержки семей, воспитывающих детей с синдромом Дауна, созданные в рамках деятельности общественных организаций и фондов Ассоциация родителей «ДаунсайдАп», Благотворительный Фонд поддержки людей с синдромом Дауна «Синдром любви», Региональная общественная организация «Время Перемен», Фонд поддержки детей с особенностями развития «Я есть!», Всероссийская организация родителей детей-инвалидов «ВОРДИ», Благотворительная общественная организация «Перспективы», грантовые программы АНО помощи детям "Звездный дождь", школы для родителей детей с ОВ3, федеральные и региональные ресурсные центры, службы ранней помощи, Центр лечебной педагогики (ЦЛП, Москва), «Инновационный центр «Сияние», г. Нижний Новгород, Даун-Центр, г. Санкт-Петербург, Свердловская региональная общественная организация инвалидов «Солнечные дети». Отечественные программы включают блоки информационного, социального, и психолого-педагогического сопровождения семей, воспитывающих детей раннего возраста с синдромом Дауна.

Анализ зарубежных подходов к организации поддержки семей, воспитывающих детей с синдромом Дауна, в различных реабилитационных программах (кондуктивная педагогика, опыт раннего сопровождения и программы реабилитации в США, в Германии, Великобритании и др.) показал наличие значительного многообразия таких программ.

Программа раннего развития для детей с различными нарушениями «Портедж», США; «РНБО», «Инклюжен», «Программа обеспечения независимой жизни для детей с ограниченными возможностями», «Маленькие ступеньки», так и узко специализированные программы, направленные на развитие определенных функций, например, «Развитие основных навыков движения через обучение: РОНДО», кондуктивная педагогика, поведенческая терапия, сенсорная интеграция, программы развития коммуникативно-речевой сферы, в том числе на основе альтернативных и аугментативных средств коммуникации и др.

Реабилитационные программы социального патронажа для лиц с ОВ3, предлагаемые центрами и агентствами в странах Западной Европы (Германия, Великобритания, Франция и др.), дифференцированы и персонифицированы, то есть напрямую связаны с реабилитационными потребностями ребенка и ресурсными возможностями региона, в котором он проживает. Основная функция управления и координации реабилитационного процесса принадлежит ассоциациям, имеющим различный профиль с учетом типа нарушенного развития. В сфере ответственности ассоциаций - определение генеральной стратегии реабилитационного процесса конкретно- 
го ребенка и его семьи, осуществление массовой информационной поддержки, а также координация, оценка и контроль качества предоставления реабилитационных услуг реабилитационными учреждениями, определение их соответствия национальным стандартным требованиям оказания реабилитационной помощи.

Период активного развития в России реабилитационной помощи детям с ОВЗ и членам их семей происходил в соответствии с трансформацией моделей инвалидности и сменой сегрегационных моделей оказания им помощи, характерных для первой половины XX века, на интеграционно-инклюзивные модели, появившиеся в конце XX - начале XXI века. В этот период появляются новые исследования, отражающих различные вопросы изучения и оказания помощи семьям, воспитывающим детей с ОВ3 (Смирнова А.Н., 1982; Белопольская Н.Л., 1984; Мастюкова Е.М., Бабенкова Р.Д., 1985; Мамайчук И.И., Мартынов В.Л., Пятакова Г.В., 1989; Добровольская Т.А., Шабалина Н.Б. 1994; Левченко И.Ю., Ткачева В.В., 2005, 2008, 2014; Шипицына, 1999, D.G. Moore, J.M. Oates, R.P. Hobson, J. Goodwin, 2002; D. Spiker, G.C. Boyce, L.K. Boyce, 2002; Панарина Л.Ю., 2004; Пальмов О.И., Мухамедрахимов Р. Ж., 2008; Айвазян Е.Б., 2016; Одинокова, Г.Ю., 2016; Ковалева Г.А., Павловская Н.Т., Кнышева Е.Р., 2017; и др.). В новых исследованиях авторы отмечают проблему изменения содержания реабилитационных потребностей семей, воспитывающих детей с синдромом Дауна, на разных этапах онтогенеза $[2,3,4,5,6]$.

Анализ реабилитационных потребностей семей, воспитывающих детей раннего и дошкольного возраста с синдромом Дауна, показывает, что их содержание изменяется в зависимости от возраста ребенка.

В раннем возрасте более 98\% семей испытывают потребность в информационной и консультативной поддержке, более $90 \%$ семей нуждаются в обучении навыкам ухода, взаимодействия и формировании специальных компетенций, связанных с ранней специализированной стимуляцией физического, сенсорного, когнитивного, социо-эмоционального и коммуниктаивно-речевого развития как базовых компонентов социализации.

Среди других значимых потребностей отмечается запрос на помощь в решении юридических вопросов (82\%), в адаптации жилья, структурировании пространства и создании в квартире реабилитационной среды, соответствующей двигательным и психологическим особенностям ребенка с синдромом Дауна (54\%), в осуществление пролонгированного медико-социальнопсихологического патронажа (86\%). Потребность в психолого-педагогической поддержке выявляется у $100 \%$ семей.

В разных странах (по данным социологических ис- следований) потребность в формировании навыков ухода, социально-коммуникативного взаимодействия, восстановлении эмоционально- личностного благополучия и навыков адаптации среды и оптимизации социальнобытового функционирования сформулировали более 85\% семей, воспитывающих детей разного возраста с синдромом Дауна.

С учетом структуры имеющихся потребностей, нами составлена Программа персонифицированного сопровождения членов семей, воспитывающих детей раннего возраста с синдромом Дауна. Программа имеет модульную структуру и включает:

1. Модуль физического восстановления родителей, целью которого является восстановление физического статуса, обеспечение ежедневных базовых физиологических потребностей (питание, сон, двигательная активность, прогулки и пр.)

2. Модуль психологического тренинга и восстановления психо-эмоционального статуса родителей

3. Модуль формирования навыков бытового приспособления, который нацелен на оптимизацию повседневной жизнедеятельности,

4. Модуль формирования рекреационных компетенций, включающих разные виды совместной развивающей досуговой деятельности,

5. Модуль формирования специальных родительских компетенций в сфере двигательного развития детей с синдромом Дауна на раннем этапе онтогенеза.

6. Модуль формирования специальных родительских компетенций в сфере сенсорного и когнитивного развития детей с синдромом Дауна на раннем этапе онтогенеза.

7. Модуль формирования специальных родительских компетенций в сфере социо-эмоционального развития детей с синдромом Дауна на раннем этапе онтогенеза.

8. Модуль формирования специальных родительских компетенций в сфере коммуникативно-речевого развития детей с синдромом Дауна на раннем этапе онтогенеза.

9. Модуль формирования родительских компетенций в сфере коррекционно-образовательной деятельности.

Данная программа апробировалась в рамках экспериментального исследования на базе группы «Вместе с мамой» для детей с синдромом Дауна в студии ООО «Цветы жизни» ЮЗАО г. Москвы в 2019 -2020 годах. В работу была включена 21 семья, воспитывающая детей раннего возраста, в том числе 18 матерей и 6 бабушек. Сравнительный анализ уровня сформированности родительской компетентности, анкетирование и оценка уровня тревожности родителей, включенных в экспериментальную работу, на начальном этапе и в конце апробации 
экспериментальной программы показал улучшение как эмоционального состояния матерей, так и состояние их знаний и навыков, необходимых для раннего развития и коррекции нарушений детей раннего возраста с синдромом Дауна. В дальнейшей части нашего исследова- ния предусмотрена оценка эффективности проведенной работы и выявление корреляционных связей между показателями двигательного, когнитивного и речевого развития ребенка и уровнем сформированности родительской компетентности у членов его семьи.

\section{ЛИТЕРАТУРА}

1. Булыгина Т.Б. Психологическое сопровождение семьи в рамках российско-германского проекта «Родительское Кафе»: опыт и перспективы [Текст] / Т.Б. Булыгина // Казанский педагогический журнал. - 2015. - №4 (111). - Часть 2. - С. 389-392.

2. Ковалева Г.А. Психолого-педагогическое изучение семей, воспитывающих детей с ограниченными возможностями здоровья, в психоневрологическом отделении / Г.А. Ковалева, Н.Т. Павловская, Е.Р. Кнышева // Коррекционная педагогика: теория и практика. - 2017. - №2(72). - С. 81-96.

3. Красильникова Е.Д. Психологические характеристики семей, воспитывающих детей с различными вариантами нарушения психического развития [Электронный ресурс] / Красильникова Е.Д., Никольская И.М. // Клиническая и специальная психология. - 2012. - №4. Режим доступа: URL: http:// psyjournals.ru/psyclin/2012/n4/57308.shtml (дата обращения: 10.06.2020)

4. Левченко И.Ю., Психологическая помощь семье, воспитывающей ребенка с отклонениями в развитии [Текст] / И.Ю. Левченко, В.В.Ткачева. М.: Просвещение, 2008.

5. Одинокова Г.Ю. Общение матери и ребенка раннего возраста с синдромом Дауна / Г.Ю. Одинокова. - М.: Полиграф сервис. - 2016. - 210 с.

6. Приходько О.Г. Система ранней комплексной помощи детям с ОВЗ и их родителям / О.Г. Приходько, И.Ю. Левченко, Е.А. Екжанова, Р.А. Даирова, М.В. Браткова, Н.Ю. Григоренко, А.А. Гусейнова, В.В. Мануйлова, Д.Э. Новикова, В.В. Олешова, Г.Ш. Тюрина, О.В. Югова, Е.А. Усанова, М.В. Шешукова // Сер. Раннее развитие и коррекция. М. : Парадигма. - 2018. - 377 с.

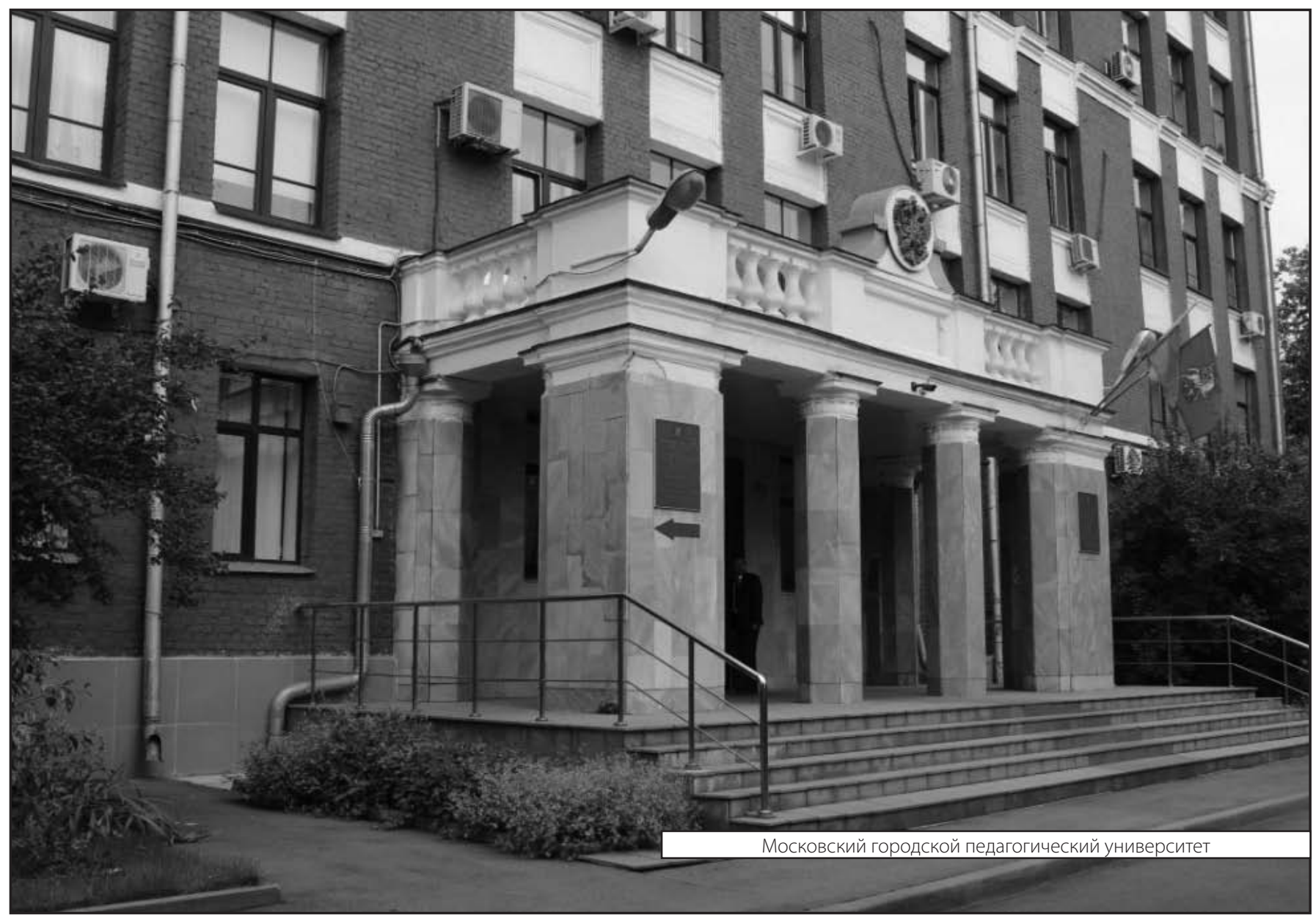

